\title{
Investigation on health conditions of flounder and smelt in the Elbe estuary
}

\author{
A. Köhler ${ }^{1} \&$ F. Hölzel ${ }^{2}$ \\ ${ }^{1}$ Zoologisches Institut und Zoologisches Museum, Universität Hamburg; \\ Martin-Luther-King-Platz 3, D-2000 Hamburg 13, \\ and \\ ${ }^{2}$ Universitäts-Krankenhaus Hamburg-Eppendorf, Martinistr. 52; \\ D-2000 Hamburg 20, Federal Republic of Germany
}

\begin{abstract}
Since 1958 the occurrence of flounder (Platichthys flesus L.) and smelt (Osmerus eperlanus L.) in the lower River Elbe has shifted gradually toward the mouth of the river into the North Sea; this may be due to periodical deprivation of oxygen and fluctuating peaks of toxic nitrite concentrations. The interior organs of both fish species caught in the Elbe estuary were examined. Macroscopic inspections revealed discolouring of the liver to be most pronounced in specimens 2-3 years of age. Cross-sections of the liver demonstrated histopathological symptoms of oedematous degeneration in smelt ${ }_{r}$ and extreme lipoid vacuolation in flounder increasing with size and age of the fishes. The intestine of both species investigated showed massive desquamation defects of the mucosa, occurring in smelts shortly after hatching, and in flounders after immigration into the estuary. The observations made suggest the influence of toxic compounds distributed in the aquatic environment on the health of both species.
\end{abstract}

\section{INTRODUCTION}

For the last 25 years, the River Elbe from Hamburg downstream to its mouth has been vastly affected by the commercial use of the waterway as main drainage channel. The increase in the density of population and of industrial settlements led to severe damage to the natural ecosystem, reflected by changes in the occurrence and distribution patterns of fish species typical of the lower Elbe area (Podloucky, 1975; Wilkens \& Köhler, 1977).

Due to damming and the discharges from developing industries, the flourishing fishery of commercially utilized prime fish species such as sturgeon, salmon, and houting diminished towards the end of the last century (Bauch, 1958; Dunker \& Ladiges, 1960). The occurrence of eel-pout, lamprey, and perch has decreased considerably in the last 15 years (Wilkens \& Köhler, 1977). Only during periods of large water supply from the upper Elbe was the influence of the industrial settlements and the domestic sewage on the water quality of the lower Elbe reduced; this led temporarily to partial restoration of pre-industrial ecological conditions (Wilkens \& Köhler, 1977).

The present study was performed in 1978 with the purpose of obtaining information on the state of health of Elbe fish as a possible indicator for the water quality. Of the commercially used fish species whose distribution has been investigated in recent years, flounder (Platichthys flesus) and smelt (Osmerus eperlanus) were selected for this study. 
Both are estuarine species, differing in their spawning and migratory behaviour. The smelt lives pelagically, and migrates as adolescent from its spawning area in the lower River Elbe downstream toward the mouth. The flounder, however, migrates in early summer from its spawning area in the southern North Sea into the lower River Elbe, to live as a demersal fish in the upper layer of the river sediment.

The interior organs were analysed macroscopically and microscopically in order to reveal pathological health conditions prior to changes detectable by external inspection of the fish. Fin erosion and ulcers, lymphocystis and epidermal papillomas were reported to occur in fish of various aquatic regions highly polluted by human refuse (Möller, 1979; Sindermann, 1979). It was the purpose of this study to investigate the beginning and the course of histopathological alterations of the interior organs of flounder and smelt. The exposure to Elbe water at different stages of the development was assumed to affect flounder and smelt differently.

\section{MATERIALS AND METHODS}

The region downstream of Freiburg, between streamkilometer 695 and 723 was chosen as collection site (see Fig. 2). Samples of fish were taken at three different locations: (1) at Medem Sand across from Cuxhaven, streamkilometer $720 ;$ (2) in midstream, opposite the nuclear power plant at Brunsbüttel, streamkilometer 693 ; (3) at the fine rake of the influx of the cooling system in the nuclear power plant of Brunsbüttel. For catches in the open river, a dragnet ("Baumkurre," $3 \mathrm{~m}$ wide, mesh size of $18 \mathrm{~nm}$ ) was used.

Samples were collected from May to November; this excluded physiological alterations of the interior organs due to the stages of low food intake during winter and to seasonal shifts of the gonadal development in spring (Weis, 1972).

Immediately after hauling, the fish were killed and, upon dissection, the interior organs were examined by macroscopic inspection. Small pieces of liver, kidney, spleen, and the gastro-intestinal tract were removed immediately from the freshly killed fish, and preserved in phosphate-buffered $4 \%$ formalin. After fixation, the specimens were processed by conventional histological procedures, and embedded in paraffin (Paraplast, Sherwood, Med. Industries, St. Louis, Mo.). Slices $(5 \mu \mathrm{m})$ were cut with a rotational microtome (Porter-Blum, Sorvall Inc., Newtown, Conn.), stained in Mayer's Hemalum (Merck, Darmstadt) for $5 \mathrm{~min}$, in $0.1 \%$ aqueous Eosin (Merck) for $20 \mathrm{~min}$, and finally embedded in Eukitt (Kindler, Freiburg). Microphotographs were taken on Kodak Panatomic-X film.

In total, 100 flounders and 90 smelts were examined by macroscopic or microscopic inspection. Flounders were sorted into 3 to 5,6 to 8,11 to 19 , and 20 to $31 \mathrm{~cm}$ length groups. Smelts were divided into groups of 4 to 5,6 to 8,10 to 15 , and 16 to $24 \mathrm{~cm}$. The first two groups represented the young fish hatched in the year of their capture. The third and the fourth groups contained fish of one year, and two years of age and older, respectively.

Ten samples each of flounder and smelt, 3-4 years of age, were taken in the Eider estuary in late summer of 1978 ; in contrast to the Elbe estuary, this area is scarcely polluted. The data obtained from measurements of the Elbe water quality, which were used for the water-quality length profiles, were kindly supplied by "Untersuchungsstelle für die Wassergüte der Elbe," Hamburg. 


\section{RESULTS}

\section{Oxygen and nitrogen concentrations of the Elbe water}

The water quality of a river can be recognized easily by determinations of oxygen and inorganic nitrogen concentrations. By these criteria, and especially during times of low water flow, the municipal area of Hamburg exerts an enormous influence on the conditions of the River Elbe. The resulting seasonal oxygen deprivations can be lethal to the majority of organisms.

During periods of large water supplies from the upper Elbe, the water quality downstream from Hamburg may be improved. As examples, two water-quality length profiles are shown in Figure 1. At a water flow of $398 \mathrm{~m}^{3} / \mathrm{s}$, the River Elbe conveyed relatively large concentrations of inorganic nitrogen at Schnackenburg. The oxygen content improved from $45 \%$ to $63 \%$ saturation between streamkilometers 550 and 610 . In the Hamburg port region (St. Pauli), a decrease of $\mathrm{NH}_{4}{ }^{+}-$levels and an increase of $\mathrm{NO}_{2}^{-}$and $\mathrm{NO}_{3}^{-}$were observed obviously caused by intensified nitrification processes. $\mathrm{NH}_{4}{ }^{+}$can be oxidized to $\mathrm{NO}_{2}^{-}$by bacteria of the Nitrosomonas group (Schöberl \& Engel, 1964). The extreme increase of unstable nitrite, measured at Hamburg St. Pauli (streamkilometer 625), was followed by continuous oxidation to nitrate involving significant oxygen consumption, possibly caused by the activity of Nitrobacter species (Boon \& Laudelout, 1962; Schöberl \& Engel, 1964). Thus, oxygen levels as low as $20 \%$ of

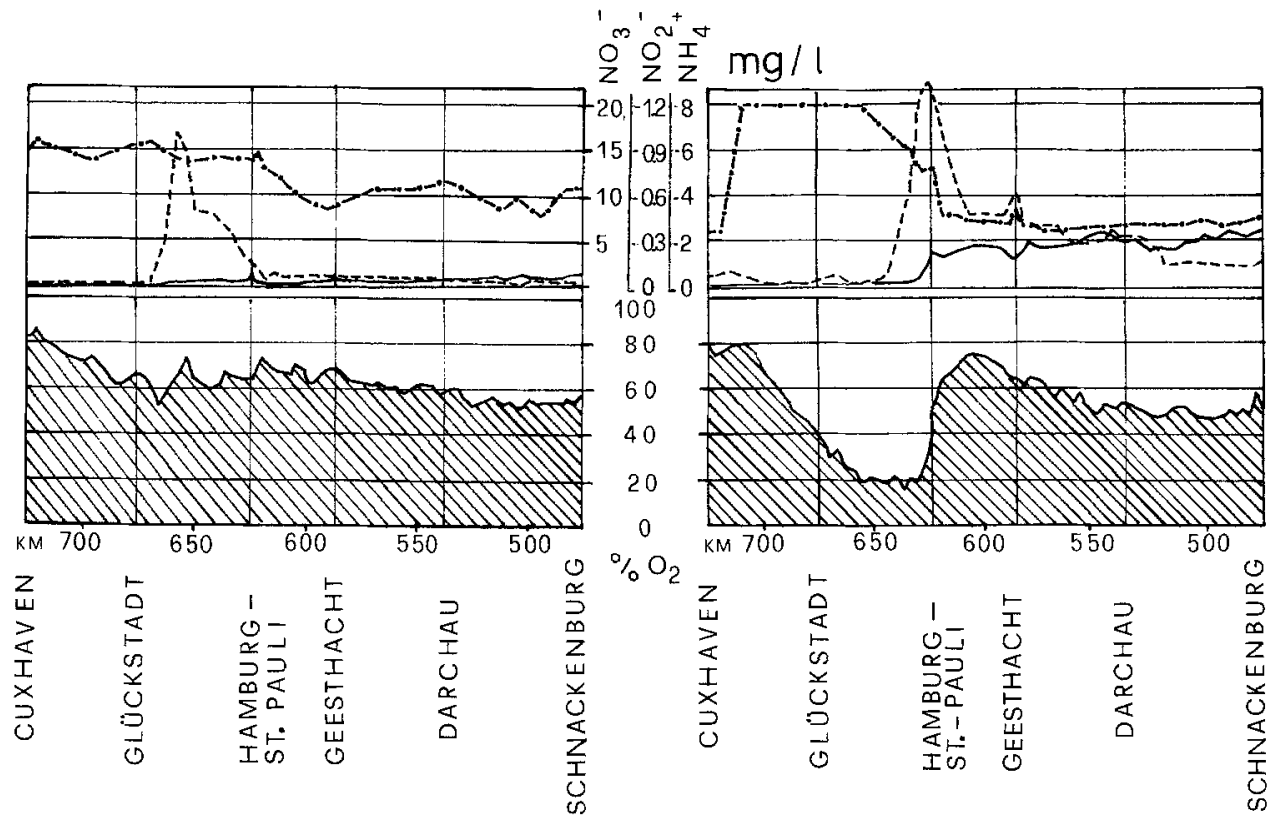

Fig. 1. Oxygen and nitrogen profiles between Schnackenburg and Cuxhaven during high or better than average water influx from the upper Elbe river, Concentration of $\mathrm{NH}_{4}{ }^{+}-\mathrm{NO}_{2}{ }^{-},-{ }_{t}$ $\mathrm{NO}_{3}{ }^{-}-\cdots-$ in $\mathrm{mg} / \mathrm{l}$. Oxygen content in $\%$ of saturation III. The water flow was measured at Darchau and at the temperature of $19.3^{\circ} \mathrm{C}$. Left: water flow of $1280 \mathrm{~m}^{3} / \mathrm{s}$ on July 10/11, 1958. Right: water flow of $398 \mathrm{~m}^{3} / \mathrm{s}$ on July $9 / 10,1963$ (data provided by "Untersuchungsstelle für die Wassergüte der Elbe,' Hamburg) 
saturation were measured in the area between Hamburg and Glückstadt. Downstream toward the mouth of the river, the oxygen content regenerated to $80 \%$ saturation, measured at Cuxhaven.

In addition to the nitrogen influx from the upper Elbe, and especially during low amounts of water supply, the concentration of inorganic nitrogen appears to increase considerably in the region downstream of Hamburg, indicated by $\mathrm{NO}_{3}{ }^{-}$levels exceeding $20 \mathrm{mg} / \mathrm{l}$. Since the average of the median levels of the water flow in summer of the years 1951 to 1970 was $270 \mathrm{~m}^{3} / \mathrm{s}$, measured at Darchau, oxygen starvation periodically took place in the area from Hamburg to Glückstadt (Wassergütestelle Hamburg, personal communication).

On the left panel of Figure 1 oxygen and nitrogen concentrations at a period of high water influx from the upper Elbe river are presented. The enlargement of the water volume restored the oxygen levels to about $65 \%$ saturation in the Hamburg area. As expected, the $\mathrm{NO}_{3}{ }^{-}$concentration increased in the region of Hamburg from 10 to $15 \mathrm{mg} / \mathrm{l}$. But additional nitrogen influx was obviously not enough to induce oxygen starvation in the downstream area from Hamburg to Glückstadt. The levels of $\mathrm{NH}_{4}{ }^{+}$and $\mathrm{NO}_{2}{ }^{-}$stayed low at around 2 and $0.2 \mathrm{mg} / \mathrm{l}$, respectively; only from streamkilometer 640 to 670 was a considerable peak of nitrite observed; this was possibly induced by the influx of the highly polluted tributaries Pinnau and Krückau. Over the total length of the lower River Elbe, the oxygen content did not decrease significantly. From Glückstadt to the mouth of the river, the oxygen levels even increased up to $80 \%$ saturation.

The data on the interdependence of water flow and nitrogen/oxygen correlations are available for the last 28 years (Wasserguitestelle Hamburg, 1950-1972; ARGE Elbe, 1972-1978). Longer-lasting improvements of the nitrogen/oxygen conditions were concomitant with a back-shift of the fish distribution, reflected in a considerable increase of the yields of flounder and smelt caught at Pagensand (Köhler, unpublished).

\section{Distribution of flounder and smelt}

The main locations where flounder and smelt were caught in the lower Elbe region and the yields of the last 28 years have been reported previously (Wilkens \& Köhler, 1977). The distribution areas were derived from these data. Figure 2 shows that within 20 years the upper ranges of distribution of the two species shifted gradually toward the mouth of the River Elbe. The main spawning area of the smelt until 1950 extended from Drage (streamkilometer 592) to Pagensand (streamkilometer 660) in the River Elbe (Ehrenbaum, 1896; Lillelund, 1961). From 1958 on, this region was less intensively utilized for spawning. Until 1965, the main fishing sites for spawning smelt were in the area between Schulau and the mouth of the tributary Liuhe (streamkilometer 655). Thereafter, the yields of smelt decreased in this region, whereas they increased in the Oste tributary and Brunsbüttel (streamkilometer 697). At the present time, this is also the main spawning area of the smelt which has shifted more than 100 kilometres downward from its original site.

In a similar manner, the upper distribution limits of flounder started to move from the port of Hamburg in the early 1950's toward Pagensand until 1965. In 1975 the upper limit of its main distribution was at Freiburg. Since 1979, the main area where the 
flounder is captured in commercially still profitable amounts has shifted downstream from Otterndorf, predominantly at Medem Sand in the mouth of the River Elbe.

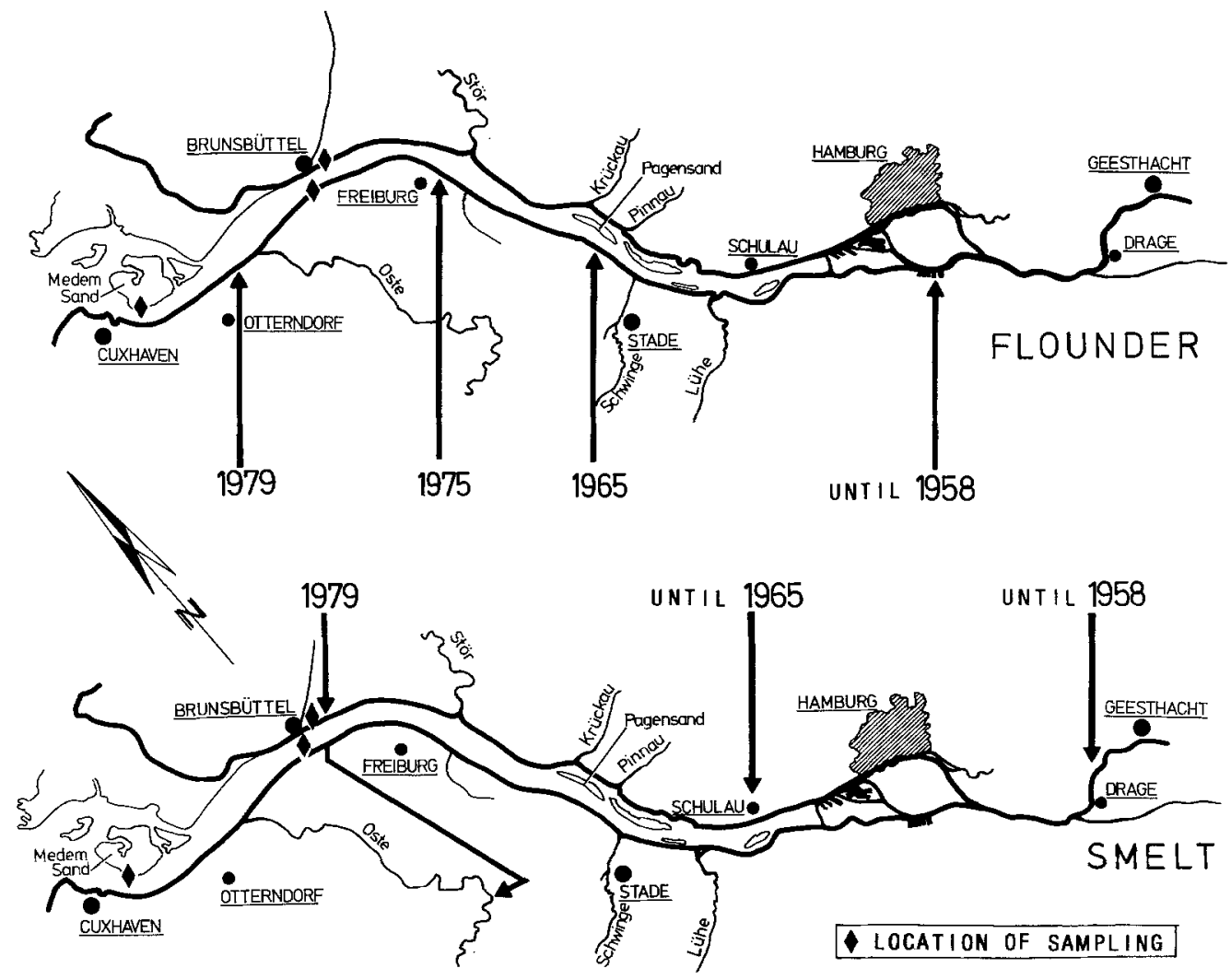

Fig. 2. Upper ranges (arrow) of the main areas of distribution for flounder and smelt in the lower Elbe river from 1958 to 1979

\section{Macroscopic examination of the liver}

After dissection of the freshly caught fish of both species, the inspection of the interior organs - when compared with fish from the River Eider - revealed alterations of the normal red-brown colour of the liver in animals longer than $6 \mathrm{~cm}$ (Table 1). The livers of fish older than three months $(8 \mathrm{~cm}$ and longer) were pathologically discoloured up to the stages of yellow white, mostly found in fish of $10 / 11 \mathrm{~cm}$ in total length equivalent to 1 year of age and older. Bleaching of the liver of flounder and smelt is regarded as a valuable indicator for severe liver disease (Roberts, 1978). Smelt and flounder caught in a region of low pollution, the Eider estuary in the North Sea, kept the normal red-brown colour of the liver to the age of 3-4 years, the time until which we investigated them.

In addition, the interior organs of the fish were screened for infection by parasites. Table 1 shows that infections of the liver by nematodes occurred later than discolouring; this event could not be observed before flounder and smelt measured 10 to $11 \mathrm{~cm}$ in total length. The nematodes associated with the liver have not yet been identified. 
Table 1. Age-dependent alterations of colour and infection with nematodes of the livers in flounder and smelt. Numbers of fishes examined are indicated

\begin{tabular}{|c|c|c|c|c|c|c|c|c|}
\hline \multirow[t]{3}{*}{ Flounder } & \multicolumn{8}{|c|}{ Total length $(\mathrm{cm})$} \\
\hline & \multirow{2}{*}{\multicolumn{2}{|c|}{$\begin{array}{ll} & 3-5 \\
\text { liver } & \text { nematodes }\end{array}$}} & \multirow{2}{*}{\multicolumn{2}{|c|}{$\begin{array}{ll} & 6-8 \\
\text { liver } & \text { nematodes }\end{array}$}} & \multicolumn{2}{|c|}{$11-19$} & \multicolumn{2}{|r|}{$20-31$} \\
\hline & & & & & liver & nematodes & liver & nematodes \\
\hline 0 red brown & 13 & & & & & & & \\
\hline 1 light brown & & & 1 & & 1 & & & \\
\hline 2 orange brown & & & 2 & & 16 & 10 & & \\
\hline 3 ochre yellow & & & 5 & & 20 & 8 & 1 & 1 \\
\hline 4 yellow white & & & & & 13 & 2 & 6 & 5 \\
\hline \multirow{4}{*}{ Smelt } & 13 & 0 & 8 & 0 & 50 & 20 & 7 & 6 \\
\hline & \multicolumn{8}{|c|}{ Total length (cm) } \\
\hline & \multicolumn{2}{|r|}{$4-5$} & \multicolumn{2}{|c|}{$6-8$} & \multicolumn{2}{|c|}{$10-15$} & \multicolumn{2}{|c|}{$16-24$} \\
\hline & liver & nematodes & liver & nematodes & liver & nematodes & liver & nematodes \\
\hline 0 red brown & 3 & & & & 1 & & & \\
\hline 1 light brown & 1 & & 3 & & & & & \\
\hline 2 orange brown & & & 8 & & 10 & 4 & 1 & 1 \\
\hline 3 ochre yellow & & & 1 & & 8 & 2 & 1 & 1 \\
\hline 4 yellow white & & & 1 & & 4 & 1 & 4 & 2 \\
\hline$\Sigma$ & 4 & 0 & 13 & 0 & 23 & 7 & 6 & 4 \\
\hline
\end{tabular}

\section{Histological findings}

The investigation of the interior organs revealed that flounder and smelt shared a number of common features in the histopathological conditions. In the intestine, one of the milder forms of the histopathological alterations seen in young fish was a massive desquamation of the epithelium (Fig. 3a). The submucosa was infiltrated occasionally with lymphocytes, and the small intestinal vessels were congested. The most aggravated conditions (total ulcerous lesion of the mucosa) were found in fish older than two months: the architecture of the villi was largely destroyed, the intestinal epithelium had disappeared, and bleeding into the lumen was noticed frequently. These are symptoms of severe ulcerous enteritis. Even macroscopic inspection of the guts revealed symptoms of the disease indicated by a viscous purulent secretion into the intestinal lumen.

For comparison, Figure $3 \mathrm{~b}$ shows parts of the intestine of a 3-year-old flounder caught in the relatively unpolluted Eider estuary. The epithelial layer and the architecture of the villi are in excellent condition, and goblet cells can be seen interdispersed in the prismatic epithelium.

In both species the alterations of the liver structure began with an unspecific swelling of the cells, a liver oedema. In the further course of the disease, however, the symptoms in flounder and smelt developed differently. A cross-section of the liver of a smelt (20 cm in total length), approximately 3-4 years of age, is shown in Figure $4 \mathrm{a}$. The blood vessels are extremely congested, and the lobular structure has largely disappeared. Most of the cells of the liver parenchyma are isolated and shrunk. The cellular 

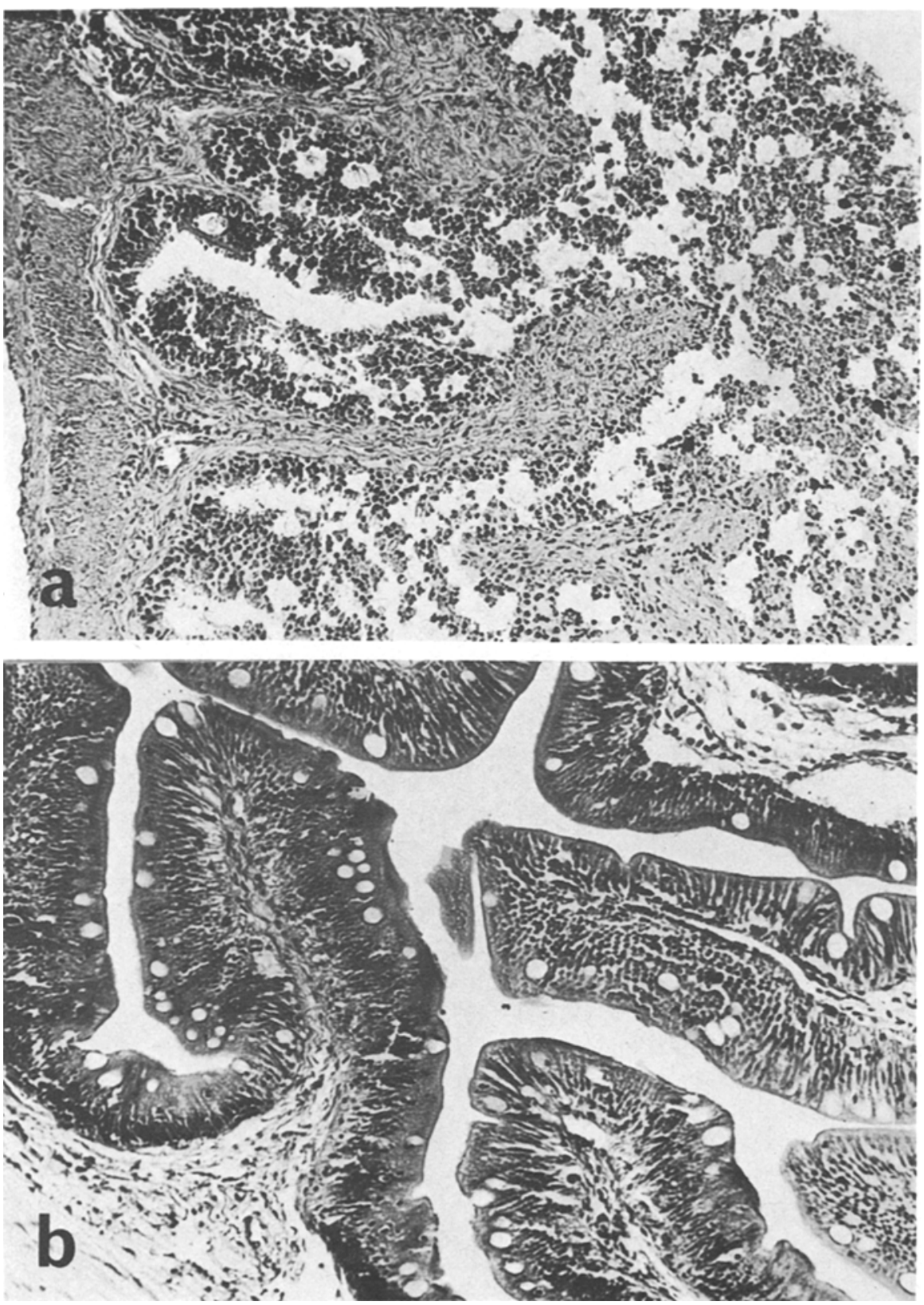

Fig. 3. (a) Cross-section of the intestine of a young flounder ( $7 \mathrm{~cm}$ in total length), 8-10 weeks after immigration into the Elbe river $(240 \times)$. (b) Intestine of a flounder $(20 \mathrm{~cm}$ in total length) caught in the Eider estuary $(240 \times)$

borderlines start to disintegrate in some parts of the section. Some of the nuclei are pyknotic. 

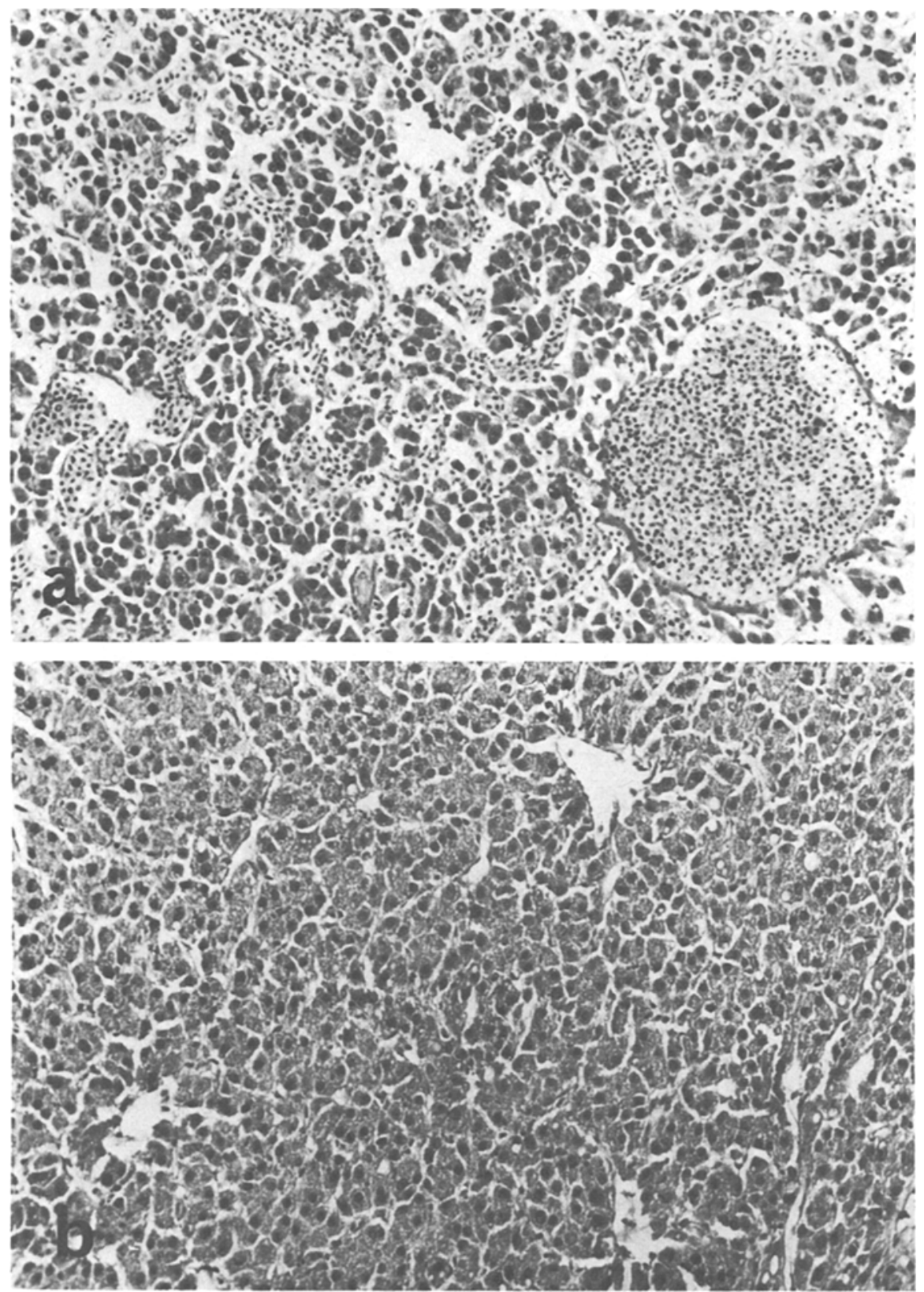

Fig. 4. (a) Disintegration of the lobular structure, and extreme swelling of the liver in smelt $(20 \mathrm{~cm}$ in total length; $240 \times$ ). (b) Liver of a smelt caught in the Eider estuary, $21 \mathrm{~cm}$ of length equivalent to $3-4$ years of age $(240 \times)$

In contrast, Figure $4 \mathrm{~b}$ shows a cross-section of the liver of a smelt belonging to the same age group (21 cm in total length), and caught in the Eider estuary. No swelling of 

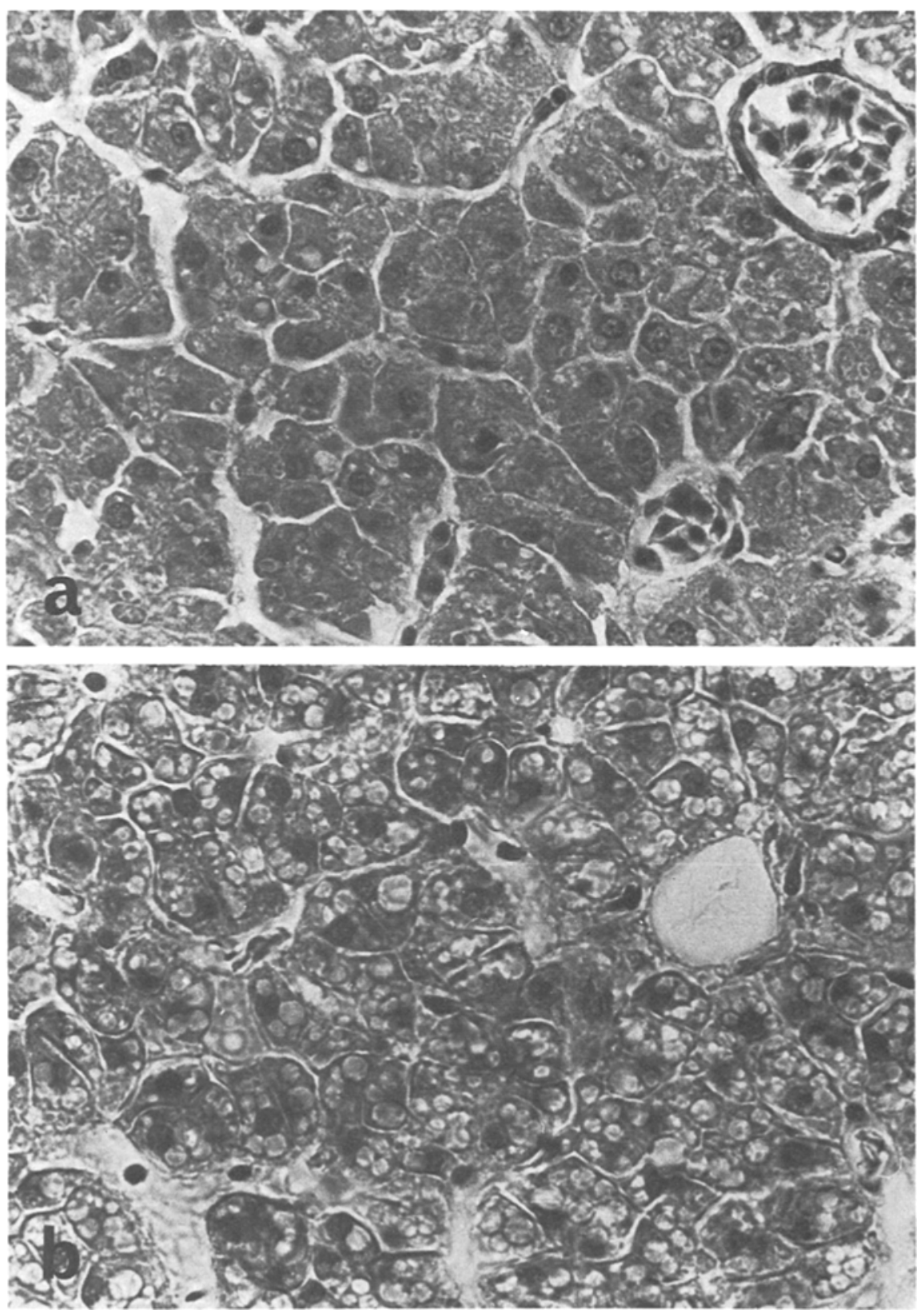

Fig. 5. (a) Cross-section of a liver of a young flounder (4 $\mathrm{cm}$ in total length) caught shortly after immigration into the Elbe river $(945 \times)$ ). (b) Extreme intracytoplasmic lipoid vacuolation in the liver of a flounder ( $21 \mathrm{~cm}$ in total length) caught at Brunsbüttel $(945 \times)$

the liver could be noticed. The lobular structure of the parenchyma, only intimated in the liver of fishes (Roberts, 1978), is well preserved. The borderlines of the cells and the 
cytoplasm are unaffected. Occasionally, singular lipoid vacuoles are seen in the cytoplasm.

Figure 5a shows the liver of a young flounder (5 $\mathrm{cm}$ in total length) shortly after immigration into the Elbe estuary. The hepatocytes are arranged in a regular manner. The cellular borderlines, the cytoplasm, and the nuclei are shaped inconspicuously. Again, few vacuoles are found inside the liver cells.

The liver of Elbe flounders older than 1 year is extremely enriched with intracytoplasmic vacuoles. In Figure 5b, the cross-section of the liver of a flounder $21 \mathrm{~cm}$ long is presented. The cellular structure is largely preserved, the nuclei and the cellular borderlines are mainly unaffected, but the cytoplasm is displaced to a large extent by vacuoles with distinct linings. Some of the vacuoles are even larger than the nuclei. As could be demonstrated by staining with Sudan Black, all the vacuoles were composed of lipoid material. The symptoms shown are those of homogeneous lipoid vacuolation of the liver cells.

\section{Distribution of histopathological alterations in different size groups}

The investigation of histopathological changes of the interior organs of flounder and smelt demonstrated that the tissues were affected differently in the size groups examined. The interior organs of the young flounders revealed no pathological alterations at the time of immigration from the southern North Sea into the Elbe estuary. Early stages of the disease were manifested in young flounders approximately 2 weeks after migration into the River Elbe, although only in $10 \%$ of the animals. Eight to ten weeks later (6-8 cm in total length) the intestine of the young flounders was severely damaged, while the liver showed only minor histopathological alterations.

In the youngest age group of smelts $(4-5 \mathrm{~cm}$ in total length) histopathological alterations in liver and intestine were diagnosed in all animals, 10 weeks after hatching (estimated after Lillelund, 1961). With a delay of about $4-6$ weeks $(6-8 \mathrm{~cm}$ in total length) more serious symptoms indicating histopathological changes were found in the smelts' liver and intestine. In the guts, inflammation with total ulcerous desquamation of the epithelium was observed in 10 out of 12 animals. In this age group, the livers of all animals were affected. In smelts of two years and older, the most severe degree of liver degeneration, the coagulative type, predominated. Similarly, in flounders 1 year of age (11-19 cm in total length) the pathological alterations of intestine, liver, and kidney were more serious than in younger fish. This development progressed toward the oldest age group investigated up to homogeneous vacuolar lipoid degeneration of the liver. In this group (20-31 cm in total length) $86 \%$ of the intestines and $73 \%$ of the livers showed the most severe symptoms observed.

\section{DISCUSSION}

The increase of urban discharges and the commercial use of the River Elbe as drainage channel by the developing industrial centres apparently led to confinement of the distribution areas of both fish species investigated (cf. Fig. 2). The data presented so far suggest that the main factor limiting the upstream migration of flounder and smelt is oxygen content (Mossewitsch, 1961) of the river downstream of Hamburg Harbour. In 
addition, though usually rather short-lived, the highly toxic nitrite (Roberts, 1978) which is produced in some parts of the river up to considerable levels may influence the distribution and the health of the fishes. Presumably, it is the massive pollution by the urban discharges of the municipal area of Hamburg which leads to the peaks of nitrite concentrations in the Elbe water. The location of the peaks can fluctuate depending on the amount of water supply from the upper Elbe (Fig. 1) and on the tidal conditions. During the outgoing tide, a nitrite peak at streamkilometer 642 had been reported by Rheinheimer (1959); this coincides with the maximum nitrite concentration during high water influx (shown in Fig. 1). In addition, the oxidation of nitrite to nitrate by Nitrobacter species may be impaired by chemical pollutants, or by alkalization of the Elbe water (Ulken, 1963). The stock of flounder and smelt upstream of Glückstadt fluctuates with variations in oxygen and nitrogen concentrations. After massive increase in death rate, or downstream migrations of fish several times during the year, the stock of both species between Hamburg and Glückstadt is repeatedly regenerated by immigration of fish from the lower regions of the estuary (Köhler, unpublished).

For this reason, the sample collection for the present investigation was carried out between streamkilometer 695 and 723 of the estuary where a constant occurrence and exposition of both species to the Elbe water could be expected. In this area, the oxygen content was satisfactory, and on average 60 to $80 \%$ of saturation throughout the years 1950 to 1977 (Wassergütestelle Hamburg, personal communication).

Apart from the oxygen conditions of the lower Elbe, a decreasing gradient of pollutants toward the mouth was described by Lichtfuß \& Brümmer (1977). The water quality of the Elbe from Geesthacht to Hamburg Harbour is characterized by heavy metal pollution of levels around $18 \mathrm{ppm}$ for cadmium, $2100 \mathrm{ppm}$ for zinc, and $13 \mathrm{ppm}$ for mercury, measured in the top layer of the Elbe sediment. Downstream from Hamburg Harbour, the decreasing levels of heavy metals rise again briefly in the area of Pagensand (streamkilometer 660). Then the heavy metal pollution gradually diminishes to approximately $1 / 10$ of the levels mentioned above, presumably by mixing with less polluted sea sediments, during the alternating tides (Lichtfuß \& Brümmer, 1977). Furthermore the river is charged with seasonally fluctuating levels of pesticides stemming from industrial production and agriculture. The extent to which flow of polychlorinated biphenyls, PCB's, varying up to $7.9 \mu \mathrm{g} / 1$ measured at streamkilometer 670 (ARGE Elbe, 1978), may contribute to water pollution depends on the quantity of water influx from the upper River Elbe, and possibly on the industrial production rates.

The investigation on the health condition of the interior organs of the two fish species typical of the lower Elbe revealed that young flounders caught immediately after or during immigration into the estuary showed only minor or no pathological alterations of the interior organs. Extended residence in the estuary was accompanied by aggravation of pathological conditions found in intestines and liver. In a similar way, the internal organs of smelt were affected in the different age groups. Intestine and liver of young smelt were less damaged than the organs of older fish. The comparison of the data of the two species demonstrated that juvenile smelt in the River Elbe showed serious pathological changes of the organs investigated ten weeks after hatching. In contrast, the interior organs of the young flounders were not affected before approximately 5 months of age, two months after immigration into the River Elbe, which takes place after the metamorphosis into flatfish is completed. 
It is remarkable that in both species the pathological alterations of the interior organs were first noticed in the intestine (Köhler, 1979). This suggests that toxic compounds of the food taken up from the Elbe water might be the causative agents for the fish disease. The infestation with nematodes was not responsible for the liver symptoms observed since the pathological discolouring of the tissue developed at an earlier age than the infection with parasites (Table 1). From the symptoms and the course of the disease observed, a viral or bacterial origin of the disease can be excluded.

A number of laboratory experiments with different toxic compounds, abundantly occurring in aquatic ecosystems, were performed with fish (for review see Sprague, 1971). They were shown to induce pathological changes similar to those established by this investigation. In pinfish (Lagodon rhomboides) and spot (Leiostomus xanthurus) the PCB Arochlor 1254 caused extreme lipoid vacuolation of the parenchymal cells of the liver, accompanied by sinusoidal congestion, focal necrosis, and inclusions of pigment (Hansen et al., 1971). The coagulative type of rainbow trout liver degeneration could be induced experimentally by the exposition to Lindane (Couch, 1975). The experimental exposure of trout to levels of ammonia of $1.6 \mathrm{ppm}$ for 9 to 12 months led to degenerative alterations in the liver including cellular shrinkage, focal necrosis and dilatation of the sinusoids. In the intestinal mucosa, mild necrosis and sloughing were described (Smith \& Piper, 1975). Levels of ammonia around $2 \mathrm{ppm}$ are measured in the River Elbe regularly (ARGE Elbe, 1978). The levels fluctuate, depending on nitrification processes and seasonal influences. It remains to be seen in future studies whether the ammonia content of the Elbe water is responsible for the histopathological alterations of intestine and liver observed in our investigation. The histological examination of the intestine of salmon following exposure to DDT in the water revealed an inflammation with infiltration of lymphocytes into the submucosa (King, 1962; Marthur, 1962). Naphthalene, a toxic compound of crude oil, caused necrosis and sloughing of the intestinal mucosa (DiMichele \& Taylor, 1978). Pathological alterations of the liver can be also induced by injection or oral administration of heavy metals. For example, the injection of methyl mercury caused necrosis in the liver of channel catfish (Ictaluous punctatus) (Kendall, 1977). The exposure to crude oil led to lipoid vacuolation of moderate to heavy extent in sole (Solea solea) liver (Hawkes, 1978). The pathological effects were modulated by the presence of the trace metals lead and cadmium, occurring in petroleum (Varanasi, 1978).

The data compiled by Sindermann (1979) and Möller (1979) were mainly based on observations of external fish diseases caused by the polluted aquatic environment. Alterations of the interior organs may precede externally visible diseases. However, during our investigation, macroscopical alterations of the skin and the cutaneous organs were not found. Thus, inspection of the interior organs even in young specimens using histological techniques obviously yields more sensitive results concerning fish diseases than macroscopical examination.

The results of the experimentally produced pathological alterations of the interior organs of fish do not argue against synergistic effects of different chemical compounds polluting the water of the River Elbe which may lead to the histopathological symptoms observed in flounder and smelt. In conclusion, it can be stated that the environment of the Elbe estuary at Brunsbüttel, which is comparably even less polluted than the area between Hamburg Harbour and Glückstadt (ARGE Elbe, 1978), cannot permit satisfactory health conditions of flounder and smelt, and consequently, the occurrence of these 
two species in their present habitats will be endangered in future. The results obtained indicate that the distribution and the health of the two fish species investigated are valuable biological indicators of the water quality in the River Elbe and its estuary.

Acknowledgements. We wish to thank the "Wassergütestelle Hamburg" for providing the data on the oxygen and nitrogen concentrations of the Elbe water. The many encouraging discussions with $H$. Wilkens, Zoologisches Institut und Museum, and M. Dietel, Pathologisches Institut, UniversitätsKrankenhaus Hamburg-Eppendorf, are gratefully acknowledged. The fishermen of the lower Elbe region were of great help in providing samples of fish and exact data on the locations of fishery.

\section{LITERATURE CITED}

ARGE Elbe (Arbeitsgemeinschaft zur Reinerhaltung der Elbe), 1978. Wassergütedaten der Elbe. Ed. by Wassergütestelle Elbe, Hamburg, 44-84.

Bauch, G., 1958. Untersuchungen über die Gründe des Ertragsrückganges der Elbfischerei zwischen Elbsandsteingebirge und Boizenburg. - Z. Fisch. 7, 161-437.

Boon, B. \& Laudelout, H., 1962. Kinetics of nitrate oxidation by Nitrobacter winogradskii. Biochem. J. 85, 440-447.

Couch, J. A., 1975. Histopathological effects of pesticides and related chemicals in livers of fishes. In: The pathology of fishes. Ed. by W. E. Ribelin \& G. Migaki. Univ. Wisconsin Press, Madison, Wisc., 559-584.

DiMichele, L. \& Taylor, M. H., 1978. Histopathological and physiological responses of Fundulus heteroclitus to naphthalene exposure. - J. Fish. Res. Bd Can. 35, 1060-1066.

Dunker, G. \& Ladiges, W., 1960. Die Fische der Nordmark. - Abh. Verh. naturw. Ver. Hamburg (Suppl.) 3, 1-432.

Ehrenbaum, E., 1896. Beiträge zur Naturgeschichte einiger Elbfische. - Wiss. Meeresunters. (Helgoland) 1,54-63.

Hansen, D. J., Parrish, P. R., Lowe, J. I., Wilson, A. J. Jr. \& Wilson, P. D., 1971. Chronic toxicity, uptake, and retention of Arochlor 1254 in two estuarian fishes. - Bull. environ. Contam. Toxicol. $6,113-119$.

Hawkes, J. W., 1978. Morphology. In: Marine biological effects of OCS petroleum development. Ed. by D. A. Wolfe. Boulder, Colorado, 87-94. (NOAA Technical Memorandum ERL OCSEAP-1.)

Kendall, M. W., 1977. Acute effects of methyl mercury toxicity in channel catfish (Ictalurus punctatus) liver. - Bull. environ. Contam. Toxicol. 18, 143-151.

King, S. F., 1962. Some effects of DDT on the guppy and the brown trout. - Spec. scient. Rep., Fish. Wildl. Serv. (Fisheries) 399, 1-22.

Köhler, A., 1979. Pathologische Veränderungen der inneren Organe von Flunder (Platichthys flesus) und Stint (Osmerus eperlanus) in der Unterelbe. - Verh. dtsch. zool. Ges. 1979, 245.

Lichtfuß, R. \& Brümmer, G., 1977. Schwermetallbelastung von Elbe-Sedimenten. - Naturwissenschaften $64,122-125$.

Lillelund, K., 1961. Untersuchungen über die Biologie und Populationsdynamik des Stintes, Osmerus eperlanus (L. 1758) der Elbe. - Arch. FischWiss. 12, 1-128.

Marthur, D. S., 1962. Studies on the histopathologic changes induced by DDT in liver, kidney and intestine of certain fishes. - Experientia 18, 506-509.

Möller, H., 1979. Geographical distribution of fish diseases in the NE Atlantic. - Meeresforsch. 27, 217-235.

Mossewitsch, N. A., 1961. Sauerstoffdefizit an den Flüssen des westsibirischen Tieflandes, seine Ursachen und Einflüsse auf die aquatische Fauna. - Verh. int. Verein. theor. angew. Limnol, 14, 447-450.

Podloucky, R., 1975. Der Niederelberaum - Industrie contra Natur. - Heimat 82, 181-190.

Rheinheimer, G., 1959. Mikrobiologische Untersuchungen über den Stickstoffhaushalt der Elbe. Arch. Mikrobiol. 34, 358-373.

Roberts, R. J., 1978. Fish pathology. Baillière Tindall, London, 278.

Schöberl, P. \& Engel, H., 1964. Das Verhalten der nitrifizierenden Bakterien gegenüber gelöstem Sauerstoff. - Arch. Mikrobiol. 48, 393-400. 
Sindermann, C. J., 1979. Pollution-associated diseases and abnormalities of fish and shellfish: A review, - Fish. Bull. 76, 717-749.

Smith, C. E. \& Piper, R. G., 1975. Lesions associated with chronic exposure to ammonia. In: The pathology of fishes. Ed. by W. E. Ribelin \& G. Migaki. Univ. Wisconsin Press, Madison, Wisc., 497-514.

Sprague, J, B., 1971. Measurement of pollutant toxicity. 3. Sublethal effects and safe concentrations. - Water Res. 5, 245-266.

Ulken, A., 1963. Die Herkunft des Nitrits in der Elbe. - Arch. Hydrobiol. 59, 486-501.

Varanasi, U., 1978. Biological fate of metals in fish. In: Marine biological effects of OCS petroleum development. Ed. by D. A. Wolfe. Boulder, Colorado, 41-53. (NOAA Technical Memorandum ERL OCSEAP-1.)

Weis, P., 1972. Hepatic ultrastructure in two species of normal, fasted and gravid teleost fish. - Am. J. Anat. 133, 317-332.

Wilkens, H. \& Köhler, A., 1977. Die Fisschfauna der unteren und mittleren Elbe: die genutzten Arten, 1950-1975. - Abh. Verh. naturw. Ver. Hamburg 20, 185-222. 